\title{
IAMJ
}

INTERNATIONAL

AYURVEDIC

MEDICAL JOURNAL

\section{AYURVEDIC HERBS IN DADRU WITH SPECIAL REFERENCE TO RINGWORM - A REVIEW ARTICLE}

\author{
Chakraborty Subhrajyoti ${ }^{1}$, Shalini $^{2}$, Sah Mahesh Prasad ${ }^{3}$, Singh O. P $^{4}$ \\ ${ }^{1} \mathrm{PhD}$ Scholar, Department of Kayachikitsa, Banaras Hindu University, Varanasi, Uttar Pradesh, India \\ ${ }^{2}$ Assistant Professor, Department of Kayachikitsa, Banaras Hindu University, Varanasi, Uttar Pradesh, India \\ ${ }^{3}$ H.O.D \& Professor, Department of Panchakarma, IOM Tribhuvan University, Nepal \\ ${ }^{4}$ H.O.D \& Professor, Department of Kayachikitsa, Banaras Hindu University, Varanasi, Uttar Pradesh, India
}

Email: ayurvedacharyasubhra@gmail.com

\section{https://doi.org/10.46607/iamj0807142020}

(Published online: July 2020)

Open Access

(C) International Ayurvedic Medical Journal, India 2020

Article Received: 17/06/2020 - Peer Reviewed: 21/06/2020 - Accepted for Publication: 01/07/2020

Check for updates

\begin{abstract}
Skin is an important and most visible organ of our body. Any disease related to skin can create physical as well as psychological problems in an individual. In recent years there has been increase in the incidence of skin problems in the tropical and developing countries like India due to various factors like pollution, unhygienic condition etc. In Ayurveda all the skin disease considered in Kustha, which are further categorized into Mahakustha and Kshudrakustha. Dadru is one of the most common but miserable variety of Kustha affects the population of all age groups and it stands as a challenge to different medical systems inspite of many advances. Dadru is a Kapha Pitta Pradhan Vyadhi and the management of which includes Shodhana(elimination), Shamana (alleviation) and Bahirparimarjana (external application) Chikitsa. Dadru can be correlated with Ringworm in modern terminology. Ringworm is a common fungal skin infection otherwise known as tinea. Ringworm most commonly affects the skin on the body (tinea corporis), the scalp (tinea capitis), the feet (tinea pedis), or the groin (tinea cruris). It is the commonest single fungus group infections found in an unhygienic environment. In modern various antifungal agents like Fluconazole, Miconazole, Itraconazole etc. have been used for the treatment of these infections. In
\end{abstract}


Ayurveda, so many herbs like Cakramarda, Bakuchi, Karanja, Rasona, Haridra etc. having antifungal activity which are experimentally proved to control and treat Dadru Kustha without any adverse effect.

Keywords: Dadrukustha, Ringworm, Ayurvedic drugs, Antifungal activity.

\section{INTRODUCTION}

Skin is the largest organ of human body. Its size and external location makes it susceptible to wide variety of disorders. In Ayurveda all the skin diseases are described under broad heading of 'KusthaRoga', which are further categorized into Mahakustha and Kshudrakustha. Seven materials affected morbidly are the causative source of Kustha such as three Dosha (Vata, Pitta, Kapha) vitiated by etiological factors and four Dusya (Twak, Mamsa, Rakta and Lasika) affected with affliction by Dosha ${ }^{1}$.Ayurvedic classics have considered each type of Kustha to be a Tridoshaja manifestation. Dadru is one among the Kustha ${ }^{2}$. Acharya Charaka has included Dadru in Kshudra Kustha ${ }^{3}$, whereas Acharya Sushruta and Acharya Vagbhata have explained under Mahakustha ${ }^{4,5}$.The reason may be that they realized the severity of the disease. Clinically, Dadru looks like Kshudra Kustha, which is easily curable by simple application also. But if it is neglected, it goes into deeper tissues and take the shape of Mahakustha. At this stage Dadru is not easily curable. This is the reason why Charaka included Dadru in Kshudra Kustha while Sushruta and Vagbhata included it in Mahakustha. It involves the clinical features like Kandu, Deerghapratana, Utsanna, Mandala, Raaga, Pidakas which exhibits involvement of Kapha and Pitta. Acharya Vagbhata especially mentioned Dadru as Anusangika ${ }^{6}$. According to Ayurveda, Dadru can be treated with Shodhana(elimination), Shamana (alleviation) and $B a-$ hirparimarjana (external application) Chikitsa. According to Charaka, Dadru is characterized by raised patches associated with itching, redness and papules ${ }^{7}$.Modern science explained that the dermatophytosis is Keratinophilic, so they grow in the Keratin of the Stratum Corneum, layer of skin. Clinical features of Dermatophytosis are intense itching, annular erythematous scaly lesions, the active border consist of papulovesicular lesions and in advancing stage the lesions spread peripherally with central clearing and pigmentation ${ }^{8}$. Similarly, Madhukoshkara, a commentator of 'Madhavanidana' stated Dadru which occurs superficially having Lakshanas- Kandu(itching), Raga(redness), Pidaka (pimples) and Udagatamandala (raised patch) ${ }^{9}$.

Thus, from the above statements, one can say that the Dadru Kustha according to Ayurveda and Dermatophytosis of modern science shows symptoms wise resemblance between each other. So, Ringworm (Dermatophytosis) can be correlated with Dadru Kustha.

Ringworm or Tinea caused by dermatophytes and are often severe as well as recurrent. Dermatophytes are fungi capable of causing superficial skin infections known as ringworm or dermatophytosis. The causative fungi belong to three genera (Microsporum, Trichophyton and Epidermophyton). They can originate from the soil or animals or be confined to human skin. Clinical forms of cutaneous infection include tinea corporis (involvement of the body), tinea capitis (scalp involvement), tinea cruris (groin involvement), tinea pedis (involvement of the feet) and onychomycosis (nail involvement) ${ }^{10}$. It usually occurs in adult wearing clothes made up of synthetic material which tend to accumulate heat and humidity. Recognition and proper treatment of dermatophyte reduces morbidity, discomfort and lessen the possibility of transmission.

Tropical antifungal drugs, oral antifungal drugs and steroids are used to treat ringworm at various stages. Now a day, resistance is increasing to antifungal modern drugs. There is no sufficient data regarding Ayurvedic treatment of ringworm (Dadru).

So, there is a need to search the effective, safe and affordable Ayurvedic treatment for the management of Dadru (ringworm). 


\section{Aim \& Objectives:}

1. To analyze about Dadru Kustha with special reference to Ringworm.

2. To show the importance of Ayurvedic herbs in the management of Dadru Kustha.

Materials \& Methods:

Material- Relevant literature is referred in Samhitas, Sangrahagranthas and contemporary literature along with personal experience.

Methodology- Review study

Literature related to the title is explored from all reliable Ayurvedic and Modern journals from internet.

Conclusion has been drawn from systemic analysis, comparison and rationale.

\section{DISCUSSION}

The present article aimed at finding a safe and effective drug for managing Dadru Kustha. Dadru is manifested by appearance of discoid lesions within tractable itching. These diseases are chronic in nature, relapses after successful treatment is common and hence difficult to cure. It mostly occurs in those people who don't follow the hygienic norms or those who are immune compromised. Dadru is Kapha dominant disease besides its Rasagata manifestation ${ }^{11}$. Hence considering this Acharya Sushruta has described their treatment as application of Shodhana Lepa ${ }^{12}$ in the form of Bahirparimarjana Chikitsa and internal medicines like Kwath. Bahyarogamarga disease involves Rasavaha\&Raktavaha Srotas, Tridoshas (mainly Kapha Pittapradhan), Twak, Rakta, Lasika, Sweddushyas and Twakadhisthan. Dadru involves only Rasavaha\&RaktavahaSrotas without further involvement of successive Srotas. Acharya Sushruta describes the colour of lesions in Dadru more specifically like that of copper or like flower Atasi (linseed) and mentioned that its Pidaka are in the form of Parimandala having spreading nature (Visar-

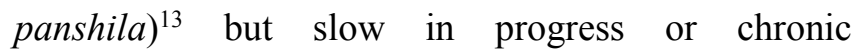
(Chirrottham) in nature with Kandu. Acharya Dalhana classified Dadru into Sitha and Asitha ${ }^{14}$. Acharyas not explained separate Nidana(etiology) for Dadrukustha. According to Acharya Charak among the six layers of six, Dadru occurs in $4^{\text {th }}$ layer ${ }^{15}$ and Acharya Sushruta mention Kustha in $4^{\text {th }}$ layer (Tamra) and $5^{\text {th }}$ layer (Vedini) among the $7^{\text {th }}$ layers of skin ${ }^{16}$.

Ringworm (Tinea) is a fungal skin disorder. The number of invasive fungal infections has dramatically increased in both developed and developing countries. An antifungal drug is used to treat fungal infection but use of such type of drug in large way makes the unusable due to resistance and its toxicity, so people move towards herbal drugs which are safer. There are numerous medicinal plants which play important role in antifungal activity.

Cassia Tora- Commonly known as Cakramarda or Ringworm plant. It contains questin, obtusin, fistucacidin, emodin, cassiaside etc as major chemical constituents. It possesses Katu rasa, Laghu\&Rukshaguna, Usnavirya indicated in Dadru and Kandu etc. It has established antibacterial and antifungal activity which helps to combat different Twakroga(skin disease $)^{17}$.The leaf extract has shown the significant antifungal activity to inhibit the growth of Candida albicans, Aspergillus niger, Saccharomyces cerevisiae and Trichophyton mentagrophyte ${ }^{18}$.It shows antifungal activity due to chrysophenol and crysophanic acid-9 enthrone and other anthraquinones such as emodine, physcion and rhein ${ }^{19}$.

Pongamiapinnata- Commonly known as Karanja or Indian beech which contain karanjin, pongapin, pongol, kanjone, glabrin, pongamin etc as major chemical constituents. It has Tikta, Katu, Kashaya rasa, Laghu, Rukshaguna and Usnavirya indicated for Kustha, Kandu, Krimi etcThe essential oil from P. pinnata showed antifungal activity ${ }^{20}$. The petroleum ether extract exhibited strong inhibitory activity against Candida albicans and Aspergillus niger. Methanol extract showed moderate antifungal activity against Aspergillus fumigates and mild antifungal activity against Microsporumgypseum and Trichophyton rubrum ${ }^{21}$.

Azadirachtaindica- Commonly known as Neem or Margosa tree. It contains azadirachtin, nimbin, nimbidin, margosinolide, azadirachtoletc as major chemical constituents. It possesses Tikta, Kashaya rasa, Laghu, Rukshaguna and Kapha-Pittahara action (Karma) which is indicated for Kustha, Kandu, Krimi etc. It is found effective in case of acute eczema, 
ringworm infestation and scabies. The antimicrobial activity of different neem extracts is well document$\mathrm{ed}^{22}$. The ethanol extracts of neem leaves showed Minimum inhibitory Concentration (MIC) and Minimum Fungicidal Concentration (MFC) against $\mathrm{T}$. rubrum and $M$. nanum. Hexane extracts of neem leaves showed antifungal activity against $T$. mentagrophytes ${ }^{23}$.

Cassia fistula- Commonly known as Aragvadha or Amaltas which contain fistulin, kaempferol, fistulic acid, rhein, sennosides A \& B as major chemical constituents. It has Kapha - Pittahara karma indicated for Kustha. Out of the five glycosides tested, CFRI (one of the glycosides) alone exhibited marked antifungal activity $^{24}$. The cassia leaf extracts are inhibitory towards pathogenic fungi (T. rubrum, M.gypseum and P.marneffei). These confirm the therapeutic claims to treat Ringworm and Skin diseases ${ }^{25}$.

Psoraleacorylifolia- Popularly known as Bakuchi or Avalguja which contains psoralen, corylifolin, psoralidin, bakuchiol, corylinetc as major chemical constituents. It has Katu, Tikta rasa, Laghu, Rukshaguna and Usnavirya acts as Kapha-Vatahara indicated in Kustha, Krimi etc. The essential oil shows antibacterial and antifungal activities which was already documented $^{26}$.The methanol seed extract of P.corylifolia comprise of a promising antifungal activity against M.furfur, Candida albicans and A. niger as compare to seed oil ${ }^{27}$.

Curcuma longa- Commonly known as Haridra or Turmeric which contains curcumene, curcumenone, curcone, curcumins, cineole etc as major chemical constituents. It possesses Tikta, Katu rasa, Ruksha, Laghuguna and Usnavirya properties. It acts as Kapha- Vatahara and indicated for Kustha, Kandu, Krimi etc ${ }^{28}$. The international literature reports on fungi control properties of turmeric pertaining to the plants extracts, the essential oil and certain bioactive constituents of the plants which may prove it as an effective fungicidal in fumigation. Arturmerone constituted $87 \%$ of the fungotoxic component of the oil. The purified ar-turmerone showed antifungal activity similar to the crude oil ${ }^{29}$.
Acorus calamus- Commonly known as Vacha or Sweet flag which contain acolamone, acoramone, acorone, cis-asarone, eugenol, calamine as mojor chemical constituents. It possesses Katu, Tikta, Laghu, Tiksnaguna, Usnavirya which act as Kapha - Vataha$\mathrm{ra}$. Cis- asarone showed antifungal activity against Helmintho-sporium oryzae ${ }^{30}$.

Allium sativum- Commonly known as Rasona or Garlic which contain number of chemical constituents like alliin, ajoene, allylmethylselenide, asparagic acid, allinase etc. It has Madhura, Lavana, Katu, Tikta and Kashayarasa, Snigdha, Tiksnaguna and Usnavirya act as Kapha- Vatahara indicated for Kandu, Krimi etc. Diallyl trisulphide showed antimicrobial activity ${ }^{31}$. Fresh aqueous extract of garlic showed antifungal activity specifically against some Aspergillus spp. Including A.fumigates, A.terreus, A.nidulans and A.niger. The inhibitory effects of fresh aqueous extract of garlic against Aspergillus spp. Were revealed in different concentrations. The inhibitory effects of allicin against Trichophytonspp are more pronounced than those of the essential oils derived from other plants $^{32}$.

Syzygiumaromaticum- Commonly known as Lavanga or Clove. It has eugenol, eugenine, eugenone, caryophellene oxide etc as major chemical constituents. It possesses Tikta, Katu rasa, Laghu, Snigdhaguna and Sita virya which acts as Kapha- Pittahara. Eugenol, the major component of clove oil, is a phenolic compound- a naturally occurring antioxidant which prevents foods from turning rancid. Its bactericidal and fungicidal properties favour its use in human medicine as an antiputrescent ${ }^{33}$.

Ocimum sanctum- Popularly known as Tulasi or Holy basil which contains eugenol, cardinene, camphene, camphor, limonene etc as major chemical constituents. It has Katu, Tikta rasa, Laghu, Rukshaguna and Usnavirya acts as Kapha- Vatahara. Essential oil from leaves showed antifungal activity is report$\mathrm{ed}^{34}$.Ocimum sanctum leaves possessed antifungal activity against clinically isolated dermatophytes at the concentration of $200 \mu \mathrm{g} / \mathrm{mL}$. MIC and MFC were high with water fraction $(200 \mu \mathrm{g} / \mathrm{mL})$ against dermatophytic fungi used ${ }^{35}$. 
Piper nigrum- Commonly known as Maricha or Black pepper. It contains piperene, citronellol, pinene, camphene, carotene, ascorbic acid, pipercide etc. It has Katu rasa, Laghu, Tikshnaguna and Usnavirya acts as Kapha-Vatahara. Essential oil reported to be antifungal against Trichophyton terrestre, Candida albicans, Aspergillus niger etc ${ }^{36}$.

\section{Probable mode of action-}

The active compounds of the above herbs like eugenol, Cis- asarone, sulfuric compounds, arturmerone, azadiradione, glycosides, linoleic acid, gallic acid, camphor, piperitone, flavonoids, phenolic compounds and tannins derived from it has antifungal effects. All the plants have very good effects against dermatophytosis agents. It found to have growth inhibition or killing effect on dermatophytosis agents and their pathogenicity ${ }^{37}$.

\section{In Ayurvedic prospective-}

Tropical preparation applied might have acted by its Ruksha and Lekhana property for pacifying the Kapha Doshas locally and maintained the equilibrium of other Doshas. The Sukshma property of drugs used might have penetrated into deeper Srotas and dissolved the Sanga. After acting locally, the impaired Dhatwagni of Rasa and Rakta might be corrected to some extent by the Agnideepana property of the ingredients. By this Dhatu Shaithilya might have resolved and provided nourishment to Twacha ${ }^{38}$.

When a Lepa is applied over the surface of skin opposite to the direction of hairs on it, through a proper base, the active principles of the ingredients of Lepa are released into that base. After that, this combination enters the Romkupa and further gets absorbed through the Swedavahi Srotas \& Siramukh and it does the cutaneous biotransformation which will pacify the Doshas and leads to breaking of Samprapti. However, it should be kept in mind that the pilosebaceous uptake i.e., absorption of Lepa differs as per the site variation, skin condition and more important is the base through which it is applied ${ }^{39}$.

The ingredients having properties like Agnidipaka, Raktashodaka, Samsrana, Pitta- Kaphahara, Kusthaghna etc., can be used to manage Dadru. Dadru is Kapha pradhana Vyadhi. Thus, formulation which contains the Katu, Tikta rasa, Ushna Virya which acts as Kaphahara can be used. In Dadrukustha, Rasa, Rakta, Mamsa, Ambu are the main Dushya as mentioned above. Rasa Dhatu Dusti is produced by Rasa Dhatwagnimandya and Jatharagnimandya. Herbs having Deepana, Pachana and Agnivardhak karma will be used for proper Dhatupaka. Herbs which are laghu, ruksha and having RaktaShodhaka properties will be used to combat and mitigate the recurrence of this disease.

\section{CONCLUSION}

In brief, Dadru Kustha is a skin disease which is correlated with the fungal skin disorder in modern medical sciences. The Ayurvedic herbs which are described above have antifungal activity which were mentioned in various researches. Modern medicines, when used for prolonging period shows toxicity and sometime develop resistance. So, for present and future perspective; some Ayurvedic herbs which are safe and effective are described. The present review summarizes some antifungal herbs which are already mentioned in Ayurvedic classics and these are helpful to mitigate the concern issue.So, there is need to do further research studies for developing new drugs in the management of Dadru Kustha.

\section{REFERENCES}

1. Sharma, PV., Charak Samhita, $1^{\text {st }}$ Edition, Varanasi, Chaukhamba Orientalia,2008, page- 455.

2. Sharma, PV., Charak Samhita, $1^{\text {st }}$ Edition, Varanasi, Chaukhamba Orientalia, 2008, Vol-II, page- 183.

3. Sharma, PV., Charak Samhita, $1^{\text {st }}$ Edition, Varanasi, Chaukhamba Orientalia, 2008, Vol-II, page- 184.

4. Singhal, G.D., Susruta Samhita, Delhi,Chaukhamba Sanskrit Pratishthan, Vol-I, 2007, page- 536.

5. Desai, Ranajitaraya., Ashtanga Sangraha, $3^{\text {rd }}$ Edition, Nagpur, Baidyanath Ayurveda Bhavana, 1986, page137.

6. Desai, Ranajitaraya., Ashtanga Sangraha, $3^{\text {rd }}$ Edition, Nagpur, Baidyanath Ayurveda Bhavana,1986, page140.

7. Sharma, R. K., Dash, Bhagwan., Caraka Samhita, Varanasi, Chowkhamba Sanskrit Series Office, Vol-III, 2013, page-325. 
8. Cook, Gordan., alimuddin, 21 $1^{\text {st }}$ edition, “Monsoon's tropical disease", 2003, page- 1173.

9. Upadhyaya, Y.N., Madhav Nidan, Varanasi, Chaukhamba Sanskrit Sansthan, part-2, page -625 .

10. Colledge, Nicki R. Et.al., Davidson's Principles and Practice of Medicine, $21^{\text {st }}$ Edition, page -1273.

11. Shukla, Vidyadhar., Tripathi, Ravidutt., Delhi, Charak Samhita, Chaukhamba Sanskrit Pratishthan, Reprint 2012, page- 184 .

12. Singhal, G.D., Susruta Samhita, Delhi, Chaukhamba Sanskrit Pratishthan, Vol-II, 2007, page- 250.

13. Singhal, G.D., Susruta Samhita, Delhi, Chaukhamba Sanskrit Pratishthan, Vol-I, 2007, page- 537.

14. Sharma, PV., Sushruta Samhita, Varanasi, Chaukhamba Sanskrit Samsthana, 2003, Vol-II, page- 38.

15. Sharma, R.K., Dash, Bhagwan., Caraka Samhita, Varanasi, Chowkhamba Sanskrit Series Office, Vol-II , 2013, page-450.

16. Singhal, G.D., Susruta Samhita, Delhi, Chaukhamba Sanskrit Pratishthan, Vol-II, 2007, page- 35.

17. Sastry, J.L.N., Dravyaguna Vigyana, Varanasi, Chaukhamba Orientalia, Vol-II, 2010, page-724-725.

18. Mukharjee, P.K., Saha, K., Das, J., Saha, B.P., Pal, M., "Antifungal activity of leaf extract of Cassia toralinn, phytother. Research., 1996,10; 521-522.

19. Acharya, T.K., Chatterjee, I.B., "Isolation of chrysophanic acid-9-anthrone, a fungicidal compound from cassia tora, Scientific Culture,1974, 40;376.

20. Sastry, J.L.N., Dravyaguna Vigyana, Varanasi, Chaukhamba Orientalia, Vol-II, 2010, page-167-170.

21. Dahikar, S.B., Bhutada, S.A., "Evaluation of Antifungal properties of Leaves of Pongamiapinnata Linn", Pharmacology Online,2017, vol-2; 40-44.

22. Sastry, J.L.N., Dravyaguna Vigyana, Varanasi, Chaukhamba Orientalia, Vol-II, 2010, page-123-127.

23. Natarajan, V., Venugopal, PV., Menon, T., "Effect of azadirachtaindica (neem) on the growth pattern of dermatophytes, Indian Journal of Medical Microbiology,2003, 21(2); 98-101.

24. Sastry, J.L.N., Dravyaguna Vigyana, Varanasi, Chaukhamba Orientalia, Vol-II, 2010, page-200-203.

25. Phongpaichit, S., et al. "Antifungal activity of Cassia alata, C. fistula and C.tora, 2004,26(5): 741-748.

26. Sastry, J.L.N., Dravyaguna Vigyana, Varanasi, Chaukhamba Orientalia, Vol-II, 2010, page-184-187.

27. Borate, A., Udgire, M., et al, “Antifungal activity associated with $\mathrm{P}$. corylifolia Linn (Bakuchi) seeds and chemical profile crude Methenol seed extract", Mint- age journal of pharmaceutical and Medical sciences, 2014, 3(3);4-6.

28. Sastry, J.L.N., Dravyaguna Vigyana, Varanasi, Chaukhamba Orientalia, Vol-II, 2010, page-513-517.

29. Kaushal,Jyoti., Gupta, M.N., "International Research Journal of Ayurveda \& Yoga" 2020,Vol-3(3).

30. Sastry, J.L.N., Dravyaguna Vigyana, Varanasi, Chaukhamba Orientalia, Vol-II, 2010, page-545-550.

31. Sastry, J.L.N., Dravyaguna Vigyana, Varanasi, Chaukhamba Orientalia, Vol-II, 2010, page-531- 534.

32. Aala, Farzad., Yusuf, Umi, Kalsom., Nulit, Rosimah., Rezaie, Sassan., "Antifungal Activity of Garlic", Iranian Journal of Basic Medical Sciences, 2014,17(3); 150 154.

33. Sastry, J.L.N., Dravyaguna Vigyana, Varanasi, Chaukhamba Orientalia, Vol-II, 2010, page-225-227.

34. Sastry, J.L.N., Dravyaguna Vigyana, Varanasi, Chaukhamba Orientalia, Vol-II, 2010, page-430-432.

35. Balakumar, S., Jeeva,S., " Antifungal activity of Ocimum Sanctum Linn(Lmiaceae) on clinically isolated dermatophytic fungi", Asian Pacific Journal of Tropical Medicine, 2011,4(8); 654-657.

36. Sastry, J.L.N., Dravyaguna Vigyana, Varanasi, Chaukhamba Orientalia, Vol-II, 2010, page-448-450.

37. Sepahvand, A., Eliasy,H., Mohammadi,M., Safarzadeh, A., Azarbaijani, K.,Shahsavari, S., Alizadeh, M., \& Beyranvand, F.(2018). A review of the most effective medicinal plants for dermatophytosis in traditional medicine. Biomedical Research and Therapy,5(6),2378-2388.

https://doi.org/10.15419/bmrat.v5i6.450

38. Shukla, Vidyadhar., Charak Samhita, Varanasi, Chaukhamba Sanskrit Pratishthan, Reprint-2012, Vol-II, page- 186 .

39. Sharma, PV., Sushruta Samhita, Varanasi, Chaukhamba Vishvabharati,2013, Vol-I, page- 11.

\section{Source of Support: Nil Conflict of Interest: None Declared}

How to cite this URL: Chakraborty Subhrajyoti et al: Ayurvedic Herbs In Dadru With Special Reference To Ringworm - A Review Article. International Ayurvedic Medical Journal \{online\} 2020 \{cited July, 2020\} Available from:

http://www.iamj.in/posts/images/upload/3907 3912.pdf 